\title{
17. Practical Church Interventions on Sorcery and Witchcraft Violence in the Papua New Guinea Highlands
}

\author{
Fr Philip Gibbs
}

\section{Introduction}

Sorcery and witchcraft beliefs and practices are common in Papua New Guinea (PNG), yet differ considerably throughout the country. ${ }^{1}$ This paper addresses witchcraft-related accusations and violence in two PNG highlands provinces: Simbu and Enga. I will explain a response from the Catholic Church in Simbu Province, and then take up a case from Enga Province, illustrating the complexities of issues raised by people in an Enga faith community that is attempting to respond to an outbreak of witchcraft-related violence in their area. I conclude with some suggestions based on the interventions to date.

\section{Highlands sanguma}

In Simbu, witchcraft, or sanguma as it is called, involves a malevolent power that is said to take the form of a creature such as a rat, bat, frog or flying fox, with the power to kill or harm people. ${ }^{2}$ The spirit-creature lives within the body of its host and even without the conscious approval of its host; the spirit-creature can take another form and roam around, eating human waste and searching for human flesh, particularly vital organs like the heart or liver (Damien 2005:128).

Because of belief in this region that spirit creatures appearing as animals like to consume corpses, people search for and kill animals in cemeteries. People in many parts of the highlands believe that if the spirit-creature is killed, then its host will die also. Moreover, by killing the host it is presumed that the spiritcreature will die, which is a fundamental belief behind the killing of people accused of sanguma. Sometimes negative feelings of jealousy and resentment are

1 See Zocca (2009). For an example from East Sepik Province, see Gibbs and Wailoni (2009).

2 In recent times people have come to view the spirit creature also in other forms - even as a helicopter or a computer virus (Bishop Anton Bal in an address to clergy conference in Mt Hagen, 24 July 2013 ). 
involved, but those killing the accused often think they are doing their duty in the sense that they feel they have to defend the clan from a malicious power that could kill again.

Beliefs such as this are common in Simbu Province and the Wahgi Valley (Jiwaka Province), but in recent times such beliefs seem to be spreading to other provinces. Eves and Kelly-Hanku (2014) refer to the spread of this belief into parts of the Eastern Highlands. There is also recent diffusion of this belief and associated violence westwards, including to Enga Province.

Enga people have a traditional belief in yama, which amounts to the personification of the malicious effects of envy. For example, if someone carrying pork or another valued food item met a person on their way home and was not willing to share, then the resultant ill feeling (conscious or unconscious) could result in illness or another misfortune for the person or the family of the one carrying the food. If a family member falls sick and people suspect yama, they might enquire who the sick person or someone else in the family had met on their way home. People say that experienced elders or a ritual expert might see or hear signs of yama (such as a whistling noise), and as a consequence recite a spell telling the person with yama to come with a recognisable sign, such as clay rubbed around their eyes, so as to be given food or some other valuable that had been put aside for them. There is an expression for this presentation in Enga: yama nenge yukingi (literally: pulling out the yama teeth). ${ }^{3}$

Formerly in Enga there was no tradition of torturing or killing people thought to be possessed by a spirit-creature such as in Simbu. However, with intermarriage and recent frequent travel to and from Simbu and Jiwaka provinces, some people in Enga now refer to a new form of yama that involves removing a person's heart and eating buried flesh. Thus one hears in Enga today a reinterpretation of yama in terms of sanguma sorcery. ${ }^{4}$

\section{Catholic bishops' statement}

The Catholic bishops from the five highlands dioceses met in May 2013 to discuss the issue of the spread of sorcery beliefs in the highlands. The bishops are convinced that a remedy will be found in strengthening people's Christian

\footnotetext{
3 I have given an example of envy over food. Another situation could be envy over how handsome a man appears at a traditional dance festival. There are also tales of how a man going hunting at night would not tell his wife, sister or mother, lest the yama of the women follow him into the forest to trick him or ruin his hunting.

4 Talk of this new type of sorcery puts the blame on women, saying that Enga women who had gone to Simbu to buy magic for restraining unfaithful husbands had mistakenly brought back sanguma as well.
} 
commitment. They produced two statements - a longer one in English to be posted in all churches, and a one-page statement in Tok Pisin to be read in all Catholic churches in the PNG highlands. ${ }^{5}$

Part of their statement reads:

We Bishops challenge our priests, religious brothers and sisters, catechists, and all church leaders and ministers, and we invite other churches too, to join with us in taking a clear, unambiguous, and strong stand against all talk about sanguma and all attempts to lay the blame on anyone, especially at the time of sickness and death. ${ }^{6}$

\section{A diocesan plan from Simbu}

Because of the tradition of sorcery-related accusations and violence in Simbu, the Catholic Church in Simbu under the leadership of Bishop Henk Te Maarssen and more recently Bishop Anton Bal have taken a stand in responding to the issue. ${ }^{7}$ During the 1980 s and 1990s Te Maarssen developed a strategy with five related components. ${ }^{8}$

\section{Help broaden people's understanding of the causes of illness and death}

The sanguma question is 'who caused the death', which is different from a biomedical question such as 'what caused the death'. Nevertheless, biomedical explanations may be accepted and may help people to consider causes other than sorcery. Parish priests and other leaders are urged to ask health workers for a medical report. If an explanation such as cancer, pneumonia or AIDS is accepted by the family they will mourn and bury the deceased with little or no talk of sorcery or sanguma. I have heard of cases where they found that the death was caused by AIDS and the mourning was curtailed, talk of 'causes' was hushed up, and the person was buried with very little talk (Gibbs 2009a:7).

\footnotetext{
5 The full English statement can be found in the last item of tokstret.com/2013/07/27/social-concernsnotes-july-2013/.

6 People from several parishes in Enga report that the statement read at the end of Sunday church services generated discussion at the time. However, further research is required to assess any long-term effect of such efforts.

7 Just over one-third of Simbu people (34 per cent) say they belong to the Catholic Church (Gibbs 2004:179).

8 Te Maarssen (n.d.) writes, 'Since the 1980s there have been increasing problems with sanguma, affecting people's social lives and leading to strive (sic) in the families. Having been parish priest in Denglagu, Gembogl district from 1982 till 1993 and in Mingende 1993-2000, I vividly recall my pastoral involvement in the problem.'
} 


\section{Early intervention before or during a funeral}

Whenever there is news of a death, the parish priest, catechist or a prominent church leader is to go to visit the family and be a pastoral presence there. (That presence may be required with leaders taking turns for several weeks or a month.) Bishop Te Maarssen comments:

If the atmosphere was still quiet I would talk with them, enquire about the dead person and his or her sickness, explain the likely natural causes, show my sympathy and pray with them. This would normally stop sanguma talk in its tracks. I also remember where a parish councillor invited me to come for the funeral and celebrate Mass for the dead person at the grave to stop sanguma talk. Sure enough, the young men were annoyed and caused some disturbance on the edge of the crowd, but the presence of God caused them to call off sanguma proceedings. (Te Maarssen n.d.)

\section{Immediate family members taking ownership}

With extended families in PNG there is a wide choice as to which family member takes ownership of the situation. Hopefully it will be a person promoting peace and harmony and not one stirring up ideas of sanguma. Unfortunately in some cases good leadership is lacking in a family, in which case the situation can easily get out of hand. Also, divisions in the family can come to the fore at such a stressful time. Bishop Te Maarssen stresses, 'Make sure that there is no family quarrel left untreated and left unsolved. So make peace, talk it over, talk it out. At the time of a funeral, people jump on anything. ${ }^{9}$

\section{Promoting respect for law and order}

Two years ago in the Nauro Gor community near Mingende two older women were being threatened that if two men who were in Kundiawa Hospital died, then those women would be 'buried' on the same day (the implication being that the women were witches). One woman was helped to escape across the Wahgi River to Neregaima and the local community police put the other under surveillance. The Nauro Gor community is fortunate in having a community law that forbids accusing another of sorcery or harming another suspected of sorcery (see Bal, Chapter 16 this volume). Offenders will be fined and if they do not pay the fine, will be sent to jail. Community policing, when functioning well, helps ensure relative order within the bounds of the community. The community police also discourage alcohol and drug abuse, which runs counter

9 Bishop Henk Te Maarssen, personal communication 28 March 2013. 
to law and order. Community policing did not prevent threats in the case of the two women mentioned, but it did help avoid greater harm. I have uncovered only one case in the Nauro Gor community of some 16,000 people in the past five years of a person being killed after having been accused of sorcery. ${ }^{10}$ There are other efforts currently to set up community law in Simbu, such as the United Kamaneku Community near Kundiawa. There have been families driven out over sorcery accusations, but no one was killed there in recent years. Both these communities and their efforts to maintain law and order are supported by churches, particularly the Catholic Church.

\section{Fostering faith to influence attitudes and emotions}

Sorcery is part of a worldview that has both similarities and differences with a biblical point of view, and considerable difference from a scientific postenlightenment viewpoint. Sorcery and sanguma are a way of explaining the existence of evil, misfortune and death. From a church perspective, death is the most unevangelised dimension of life in Melanesia (Gibbs 2009b). Churches need to contend with beliefs that challenge Christian faith. Some other mainline churches such as the Lutheran Church also contest sorcery beliefs and there are moves towards a more collaborative approach. ${ }^{11}$

One of the biggest challenges for churches in PNG is to deepen people's faith commitment in a way that Christian faith can provide an alternative to the traditional worldview when it comes to misfortune and death. People with deep Christian faith are called to believe that God is the author of life and that God permits sickness and death. Various churches have different approaches to praying for the dead. The Catholic approach at a funeral is to say, 'Pray and thank God for the gift of his or her life, and if you are really sorry then pray for him or her and for us'. This requires a shift from blame for death to thanksgiving for life.

The Catholic Church in Simbu has developed a training course and distributed 600 copies to help believers find an alternative to sanguma. They are taught that belief in sanguma and employing a diviner who uses magic to detect someone to accuse is a way of thinking that runs quite contrary to belief in the power

10 Bishop Te Maarssen is quoted estimating 150 deaths a year in Simbu of people accused of witchcraft (Zocca 2005:117). With a population of 403,722 (2011 national census), that amounts to 1 death per 2690 persons per year, or 1 death per 528 persons over five years. The 1 death over five years in the Gor community is $1 / 16,000$, which is approximately 30 times better than the whole of Simbu based on the Bishop's estimate.

11 Pastors and leaders from a number of Christian churches joined Bishop Bal in a workshop in January 2014 at Dirima parish in Simbu. A meeting of the Churches Partnership Program (CPP) in Port Moresby (27 March 2014), attended by leaders of seven mainline Churches, discussed the issue of sorcery and sorceryrelated violence. There was general consensus that there needs to be a lot more work within the body of churches to come to a shared understanding on best practices with this issue. The CPP group also asked that they could have a representative at any further conferences on the topic of sorcery. 
of God. The course acknowledges a biblical worldview and notes a number of examples where Jesus cast out demons, but Jesus never hurt a man or woman when casting out a demon. ${ }^{12}$ Ultimately, there is the fifth commandment, "Thou shalt not kill'. The bishop even added a line: 'Tekewe ol pasin bilong sutim tok sanguma' (Eradicate the custom of sanguma accusations) in the prayer following the Lord's Prayer at mass and suggested that all priests in the diocese follow suit.

In order to back up the five-point policy just outlined there are also sanctions. If a person takes part in accusing another of sanguma or of injuring someone accused of sanguma they are excommunicated from the church until they retract their accusation (Korugl 2006:3).

\section{Effectiveness of the five-point plan}

The effectiveness of the Simbu diocesan strategy is still an open question. Bishop Te Maarssen says that 'it had a restraining effect'. Bishop Anton Bal, the current bishop, thinks that it has helped reduce sanguma accusations in many parts of Simbu, particularly around the Catholic headquarters of Mingende. Still, if a young person or a high-profile person dies suddenly, church leaders have to act quickly to counter talk of sanguma. Two cases below illustrate the strategy in practice.

\section{Case 1: Death of Joe Mek Tiene}

The late Joe Mek Tiene, member for Kundiawa-Gembogl electorate, died on 25 April 2011. His sister Josephine reflects on that time:

When someone is dead they always talk about sanguma, they accuse people so then it becomes sort of a tradition, a custom to us. I have witnessed five deaths within our family but within our own family we never about sanguma. And when others want to talk about it I always come in between and always say 'no'. One reason is that I want to practise my faith and be firm in my faith. Second, my father Joseph Tiene was a catechist with Father Alphonse Schaefer. He was a disciplined man who taught us to practise our faith. The other thing is for the future generation so that we don't have this kind of atmosphere in the family. We have young girls in the family and if the girls go and marry in another place then they are going to accuse them if anything happens like that in their own family. And in their husband's family any deaths - they will blame them if they are known to come from a sanguma family. I said 'no,'

12 In Tok Pisin: Jisas i no bin paitim wanpela man o meri bilong rausim spirit nogut. 
17. Practical Church Interventions on Sorcery and Witchcraft Violence in the Papua New Guinea Highlands

and I said 'these are my family and I have the right to say it'. When Joe died our parish priest Father Simon came and also Father Willie Kuman came and they supported us and we felt at peace. Father Jaworski came too and said that it must be a heart attack because Joe was such a big heavy man. It is not easy because when I say 'no', people try to break this fence of faith surrounding our family. People turn around and say, 'Why are you so strong against us getting a glasman (diviner)? Then you must be a sanguma. 'Kumo bitno akena ga', 'You are holding the head of the sanguma and you are trying to cover up'. One day we will see who is right. The devil is confusing us. That's what I believe. I am fortunate that I have a number of strong brothers to support me, and also there is the government law, yet still people say, 'em mipela bai stretim long we bilong ples yet' (we will deal with it according to custom). ${ }^{13}$

Application of strategy in this case:

- the family is united

- there is a strong person - in this instance a woman - prepared to take ownership of the situation

- she feels supported by her brothers and by the law

- she and the family are Christians and think that sanguma talk comes from the devil

- there was an immediate supportive pastoral response by the parish priest and another priest friend

- Father Jaworski (a surgeon) provided a biomedical explanation (heart attack).

\section{Case 2: Addressing a world view}

Margaret's brother, a university student, died of tuberculosis. A number of educated family members had died tragically (in car and air accidents) and the young men were attributing this to sanguma and started agitating at the funeral. Margaret, who is a registered nurse, consulted with her husband and then stood up and told them the biomedical reason for the death. That was not enough and she realised she had to compromise. She is strong Catholic but realised that Christian arguments might not help so she addressed the worldview of the boys and said,

You have never seen a sanguma with your eyes have you? You know that sangumas turn into a dog or some sort of animal. So, after we have

13 Interview with Josephine Tiene in Kundiawa, 2 September 2013. 
buried my brother you boys watch the gravesite day and night and you can kill any animal that comes. The only thing is you must not kill a human being. I forbid you to do that. ${ }^{14}$

Having promised them some money for small projects, and with the boys on side they buried her brother, watched over the grave for three weeks, killed several animals, but to no effect. After three weeks they gave up and stopped monitoring the grave.

Application of strategy in this case:

- there is a strong person - again in this instance a woman - prepared to take ownership of the situation

- she intervened from the beginning, when her brother was ill and as soon as she heard that her brother had died

- she provided a biomedical explanation (tuberculosis) — with only limited effect

- she and the family are Christian and cannot reconcile sanguma with their faith. On faith grounds she made it clear that killing a human being is unacceptable

- she argued using the worldview of the boys so that they would understand.

Elsewhere I have discussed gender violence and witch-killing in Simbu and the fact that women are more likely to be accused of witchcraft because of their weaker social and political presence (Gibbs 2012). In both the cases above, it was women exercising a strong social presence who prevented a situation that could have resulted in accusations of sanguma and a violent response. These cases help illustrate the five-point plan promoted by the Catholic Church in Simbu to reduce witchcraft-related killings.

\section{Diffusion of sanguma beliefs to Enga Province}

There have been several cases in Enga Province in recent years of women being killed or severely hurt after having been accused of practising witchcraft. The following account about one of those cases is factual except for the change of names and some places in an effort to preserve some privacy. A young man died in Wabag Hospital (Enga). Some people say that during his funeral, while people were mourning and he had not yet been buried, word went around that the dead man had called by mobile phone and named two women, saying that they had taken his heart and this had caused his death. Men rounded up the

14 Interview with Margaret Ghunn at Mingende, 12 September 2013. 
two women and proceeded to torture them with heated iron rods and bush knives, demanding to know where they had put his heart and telling them to put it back. The women were brutally assaulted but could not respond to the men's requests. Eventually the body of the young man was buried. One woman died from her injuries. The other, terribly burned, managed to escape, spending the night partially immersed in a river and walking the next day to where she received assistance to get to a hospital in another province.

That woman survived. The doctor in his report states:

[She] remained in critical condition for the first 10-14 days in hospital ... She required three months for intensive care of her wounds ... She was seven months pregnant at the time of this assault. Her baby died and was delivered on the following day. The baby also suffered from burns even while in the uterus ... This act was one of the more cruel and inhuman acts I have witnessed in 35 years of medical practice, 17 of which I have spent in the Highlands of Papua New Guinea. ${ }^{15}$

I followed up on the incident, meeting the woman (here named Maria) shortly after she had been released from hospital. I came with her husband and it was a joy to see the two together. She was happy to see him and said that she looked forward to returning home to be reunited with her husband and children. She also wants to have her innocence declared publicly through a court hearing. For almost a year I have been meeting with the people where she comes from and it has been a learning experience for me, and for them, to find what are their concerns when faced with the prospect of Maria returning. ${ }^{16}$

\section{Concerns of the community}

I note that the concerns raised by the community are a mixture of fear and confusion.

- they fear being blamed and taken to court for supporting a person who has been declared a threat to society

- they fear that people might get violent again and she could be killed and anyone supporting her could be assaulted or also killed

- they are confused, saying that they are Christians, yet they admit they believe in witchcraft

15 The report, held by the patient, is signed by Dr Bill McCoy from Nazarene Hospital, 22 April 2013.

16 I first lived in the area she comes from for six months, some 40 years ago, and I was parish priest there for five years, starting 30 years ago, so I am not a total outsider. 
Talking it Through

- they worry too, saying that she had admitted being a witch, so why try to support such an evil person.

I will consider these four points in turn.

\section{Fear of being blamed and taken to court}

First, I spoke with church leaders, councillors, women's leaders, nurses and teachers and all were anxious lest they be blamed for supporting a person who had been expelled from the community. What if something would go wrong if someone would get sick and die? In such an instance Maria might be accused again, and then those who had helped her return would also be blamed. Some said that we should get 'permission' first from those who had tortured her. Then there would be less likelihood of others being blamed.

Some were openly afraid that the relatives of the young man who had died - that is those who had tortured and banished Maria - might summons Maria's supporters to court. After all, the deceased's relatives had gone to the trouble of ridding the community of such a dangerous person and how could people contemplate supporting her and bringing her back? That would be totally irresponsible and if necessary they would seek legal means to stop such nonsense.

Local village court officials feel uncomfortable. They had heard that the Sorcery Act has been revoked, but are not clear about their role and their legal standing in cases involving such cultural beliefs and practices. Since it was such a grave matter involving terrible physical torture and the death of an unborn child they presumed that the original case would be a matter for the district court. Yet, what if a complainant raised the matter of a person or group of people bringing an undesirable and possibly dangerous person back into the community? Would this not be a matter for the local court officials?

\section{Fear of further violence}

Second, several people were afraid that there would be further violence. Some had witnessed the torture and public humiliation that had led to the death of one woman and the expelling of another. There had been terrible physical, emotional and verbal violence the day following the torture as she had tried to get assistance at the local health centre and been turned away by armed men. Then she was abused by both men and women as she desperately attempted to escape along the road in the direction of her parent's village.

The husband of the woman who had died took his wife's assailants to the village court and was awarded compensation of pigs and money, but that had not 
turned out well and he had refused the pigs offered, saying that they were too small - thus leaving a tense unresolved situation. There has been no appeal to a higher court.

Not everyone had been against Maria. Some said that they had tried to help her but were accosted by men armed with axes and bush knives such that they abandoned attempts to help lest they too be killed or badly injured. One man said that armed men had threatened to cut his leg off if he supported her. Remembering such violence and the horror of a woman with third-degree burns over 40 per cent of her body, many people did not want to risk a repeat episode. Why return and risk further violence? Could she not remain elsewhere and let memory of the whole incident gradually fade? Maria's response is that she has done nothing wrong, so why should she have to stay away as if she is guilty.

\section{Confusion over belief in Christianity and in witchcraft}

Third, many Christians admitted that they are confused. The group directly involved in the torture are unchurched but the surrounding community is predominantly Catholic. They renew their baptismal promises every year during the Easter ceremonies, agreeing to 'reject Satan and all his works and empty promises'. In doing so they reinforce their belief in good and evil and the way good and evil can be personified - good personified in Jesus Christ and evil personified in Satan. Like most Papua New Guineans they believe in the spiritual, supernatural, or non-empirical realm. Some would call it a magical worldview.

People seek explanations for good and evil, particularly misfortune and death. Why did the tree branch fall when he was beneath it? Why was there a car accident? Why does a person die? Such questions are often phrased using 'who' questions. 'Who' caused him or her to get sick and die?

Stories are circulating around the area: of a sow that was ready to give birth and then appeared not pregnant and without piglets. Had a witch consumed the piglets before the mother could give birth? There were other stories of people killing a chicken and in gutting it, not finding the heart. Had a witch consumed the chicken's heart? Such stories only too readily prepare listeners for stories of a witch who has removed and devoured a human heart.

The church leaders at the local parish requested a two-day workshop to clarify issues. In November 2013 we had the two-day workshop, based largely on the helpful book from the Melanesian Institute, Thinking Critically about Sorcery and Witchcraft (Schwarz 2011). Ideas promoted included human rights, scientific argument and Christian faith. Afterwards participants shared how two 
topics had made a big impression. They were alarmed to hear how before the enlightenment, thousands of accused witches had died in Europe (see Stewart, Chapter 10 and Keenan, Chapter 11 this volume). The other topic that made an impression was studying the Gospels to see how Jesus had dealt mercifully with persons possessed by evil spirits - such as the healing of what appears to be a lad suffering from epilepsy (Luke 17:14-21).

We discussed how the development of science and the enlightenment provide alternative explanations for sickness and death. Science may not provide satisfactory explanations to 'who' questions, but it can usually provide explanation for 'what' questions, and for many in the workshop, that is enough if it would forestall the prospect of multiple witch killings as had happened earlier in Europe. They resolved to request more often a letter from a doctor or a nursing officer about the cause of death, rather than resorting quickly to sorcery as an explanation.

Study of healing stories in the Christian Gospels led to the issue of belief and decision-making. Participants put it in terms of a fence. If a fence around a garden is strong and intact, then a pig cannot get inside to destroy the garden. In a similar way, they could have a 'thought fence' to regulate their minds, and not be troubled by the stories circulating. There are two possibilities here. The fence could separate real from unreal, thus allowing a person to say that they don't believe in the power of sorcery. The other possibility is to have the fence separate real powers so that being kept outside the protective fence disempowers thoughts and beliefs about sorcery. Several participants witnessed that they were no longer afraid of sorcery or witchcraft and this left them feeling confident and free - in other words ideas of sorcery were disempowered. Those Christians who continued to entertain such thoughts about witchcraft stories were allowing them inside the fence and so experienced confusion with diverging beliefs. Thus it was not a matter of believing or not believing in the reality of evil, but that faith commitment gives them a sense of security in the face of evil power. ${ }^{17}$

\section{Why support a person who has admitted to being a witch?}

Fourth, in many cases I hear people saying that the accused person admitted to being a witch. For example, in the case of Kepari Leniata, the young woman burned alive in February 2013 in Mount Hagen, most people I have spoken with

17 At this point I will not dwell on the question whether Christian belief is a functional substitute for belief in sorcery. 
tell me that they believe she truly was a witch because she had admitted it, and two women from Simbu had corroborated this evidence saying they had seen her cook and consume the young man's heart.

Usually such stories have been embellished as they get passed on. In response, I ask whether the confession was made while the accused was being tortured. In all cases so far it appears that confession was extracted under extreme torture. People say that they had to use torture in order to get them to admit the fact. However, how true is confession under torture? As Nick Schwarz notes (2011:51), some people confess their guilt hoping that their assailants will simply kill them and thus relieve them of the hell of continual torture.

Even before confession there is a tendency in PNG for presumption of guilt rather than innocence. If a glasman or diviner points to a person then they are automatically presumed guilty and how can they prove that they are innocent? Courts have dismissed cases involving accusation of sorcery due to lack of evidence. However, the person being tortured or expelled from the community has little chance of successfully claiming innocence. When the Catholic sisters came to intervene in the case of a woman being tortured near Mendi in 2012, some people called out 'sanguma $i \mathrm{kam}^{\prime}$ (witches are coming). Fortunately the sisters were not deterred by such claims. However, for most people it is a terrifying thought that in defending the accused, people might point to you, and then how would you prove your innocence?

Even if a person would return, claiming innocence and appearing quite 'normal', this would still be insufficient for some. A health worker gave the example of sleepwalking. He said that a person sleepwalking is not conscious of what they are doing and might have no recall of what they had done while sleepwalking. In a somewhat analogous way the sanguma spirit is believed to leave the body of its host sleeping. Later, the person having woken might have no idea what malicious acts the sanguma spirit had performed while outside the body. How does a woman wanting to return home respond to such beliefs, particularly in a context that presumes guilt rather than innocence? This is a complex issue that people admit needs a lot more clarity.

\section{The spectrum of violence}

The issues raised in the interventions recorded above provide wider lessons for a whole spectrum of violence associated with witchcraft and sorcery, particularly the form that is spreading recently in the highlands and among people from highlands communities in coastal towns. 
It begins with the violence of what is perceived as evil or misfortune. A person sickens and dies for no explicable reason. Subsequently, violence ranges through accusations and rumours levelled at a person, usually a defenceless woman. Through this process the 'accused' becomes 'victim'. ${ }^{18}$ It often begins as verbal or emotional violence that later erupts into physical violence. Physical violence may result in serious injuries, death or banishment from the community. If one survives, the violence continues in terms of being regarded as unwelcome and undesirable. The scars are there on the body as ever-present reminders of violence suffered and the threat of even more hurt if one would return home to a community that believes in the presumption of guilt rather than innocence. In fact, some say that recovery from violence from which they should have died is further proof that the accused person really does have access to superhuman powers.

\section{A return visit}

Having recovered sufficiently from her physical wounds, Maria's dream is to have the court declare her innocence and for her to return home and be reunited with her husband and children. People from her community suggested to me that her initial visit should be a brief one in order to test the response of the community. So one weekend in November 2013 she and her husband came with me to Enga. Coming closer to the area where she had been tortured, she said she was feeling comfortable, but her body language indicated the contrary as she pulled the hood of her jacket down over her face. Then, as we drove up into the hills above Wabag, upon sighting her house across the valley, she pointed and spoke just one word, 'home'. There was a moving nostalgia about the expression, as she knew it was still too dangerous to go there. She stayed the night elsewhere with her married daughter.

The next day she and her husband attended Sunday mass at the local parish church. At the end of mass a leader (a magistrate) addressed the congregation of about 500 people, noting her presence. Afterwards the majority of adults came to her warmly with hugs and lots of tears. Admittedly these churchgoers had had little to do directly with her accusation and torture. Notably, several people present who had been implicated in the accusations and torture did not come to greet her and kept their distance. Later that afternoon we returned several hundred kilometres to another province where she currently stays. Maria reflected as we drove, saying how her accusers must have been 'jealous'

18 The term 'victim' is an ambiguous term since, depending on the point of view, the victim could be the original person who died, or it could be the person tortured or killed, having been accused of sorcery that caused the first death. 
of her because she had a good house and garden and enjoyed a happy marriage. From other cases I have encountered, jealousy seems a common motive, and a factor that calls for attention.

\section{Trouble}

Realising that the situation is far from settled, I went to speak with some of the men who had been involved in accusing and torturing Maria. They told a different story, claiming that before he died in Wabag Hospital their relative, the young man, had named Maria as being responsible for his demise.

On the very day that the young man (deceased) distributed pork with his uncle, he felt sick and said, 'Maria must have taken my heart when I was giving pork meat (liver) to my other uncle because she asked for it and I refused and saw her longing to have the liver. When I did not give her the liver, she must have taken my liver to quench her thirst/hunger'. He mentioned her name even before he died. ${ }^{19}$

They strongly believe the words attributed to the deceased and hold Maria accountable for three major problems. First she killed the young man through sanguma. Second, when accused, she had named another woman - the one who eventually died. So therefore she is responsible for the death of the other woman. Third, since she would not put back the heart of the deceased she had to be tortured in an effort to make her do so, and in the process her baby was killed, so she is responsible for that too.

The men explained their view of the torture.

The reason for torturing Maria was not to kill her. It was not done as a game or for fun. She was tortured when other people who have been living in Mount Hagen or Simbu said that the accused must have placed the heart in a cool place under a waterfall and she would eat it after the burial of the deceased. They said that if they would torture her she would take the heart and put it back and the young man would come back to life again. The general community believed that and they were desperate to have the life of the young man back again. So they believed that by torturing Maria, she would give the heart back and so they kept torturing her. They did not intend to kill her. So after spending many hours torturing her and when nothing happened, they released her. ${ }^{20}$

19 Interview with a male relative at Tieliposa, 22 March 2014.

20 Interview with a male relative at Tieliposa, 22 March 2014. 
Moreover, the men claim that Maria could possibly be responsible for a fourth serious problem. With her away the incident is gradually being forgotten, but if she tries to come back to live there, it will raise all sorts of problems. There would be trouble and even violence if she comes back intending to stay. They say that they have paid compensation for the death of the other woman, therefore as far as they are concerned, the only prudent solution for Maria is for her to forgive and forget.

\section{Conclusion}

The account of Maria's return and the response of the men who had accused her illustrates a number of issues raised in this paper. The men who tortured Maria - and I gather in many other cases too - are not just young men with a blood lust or high on marijuana. They are people caught up in conflicting beliefs about life and death. If one follows the logic of Melanesian tradition, it will usually involve discovering who is responsible for the misfortune. Moreover, if the situation is such that life or death depends on identifying the person responsible in order to convince them to reverse the effects of sorcery, then the matter will appear most urgent. If the deceased is already buried, then Melanesian tradition will turn to the future wellbeing of the local community.

The five-point plan of the Catholic Church in Simbu confronts the logic of Melanesian tradition with Christian belief that attributes life and death to God. By having an influential person present at the funeral, drawing not only on Christian faith, but also promoting a biomedical explanation of sickness and death, the church seeks to provide an alternative understanding of misfortune. That alternative was accepted in the two cases presented above from Simbu. In the case from Enga, with little previous experience of dealing with this type of sorcery accusation, the Christian community was unprepared and there was no effective alternative offered.

It is noteworthy that recent conversation within local communities in both Enga and Simbu has included discussion on a faith level including bishops' statements read out in church and circulated afterwards. Prayer groups now have passages from the Bible as a source for reflection and discussion. People are faced with the issue of how as Christians they might respond to misfortune and untimely death. Discussion on this level is important as it leads to a direct confrontation with belief in sorcery. Thus the discourse goes beyond sociocultural and legal matters to fundamental beliefs. Admittedly, many people still struggle with seemingly contradictory viewpoints, but the conversation is ongoing and this will be important for developing strategies for preventing such violence in the future. 
Maria finds herself in a difficult legal situation. She is determined that once the case of the other woman who died is resolved, she will summons to the district court the 10 or 12 men who assaulted her. But these men are close relatives of her husband. Thus it will mean taking 'family' to court. How can she settle again at home if those relatives owe her large compensation in money and pigs or, even worse, if they will be absent for long jail terms? The men have put it clearly - if she comes back there will be trouble.

From the interventions to date I offer the following six suggestions. First, there is need for both prevention and support. Comprehensive prevention strategies aim to reduce or even halt the trend of sorcery accusations and violence. Yet there are still many marginalised 'Marias' faced with a legal predicament after having suffered assault. How can such victims be supported, when the community claims that pursuit of the case will only mean more 'trouble'.

Second, the Simbu Catholic Church plan and the sorcery workshop in Enga appear to be producing helpful results. Yet that is only a beginning. Many in the Catholic community still admit their confusion and their fear of being blamed for supporting a person who is considered a threat to society. Church strategies should be pursued further and monitored for their effectiveness.

Third, the response of some other Christians - predominantly Pentecostal-type churches - is unclear. It could be that their stress on possession by evil spirits and 'deliverance' may only reinforce customary Melanesian beliefs in spirit possession associated with sanguma. This needs to be followed up in dialogue with various churches. Churches need to draw inspiration not only from scripture and theological traditions, but also human rights ideals. In PNG, given that most people profess Christianity, churches may play an important role in interpreting rights language and values into cultural frameworks meaningful to people in a given local context.

Fourth, the group who were actively involved in accusing and assaulting Maria did not attend the parish workshop and the majority are not active members of a Christian worshipping community. In such situations legal sanctions are important. The men interviewed admitted not wanting to participate in such violence ever again, as having had the village court order them to pay out pigs and money to the husband of one woman who died, they now realise that any future case will have legal consequences that could be very costly for them.

Fifth, about 50 people attended the workshop in Enga, and the Sunday congregation was large, including community leaders. This has helped identify a growing group of well-meaning people within the local community who are prepared to take a stand against sorcery accusations and violence. There 
Talking it Through

is a similar trend around Mingende and the Nauro Gor community in Simbu. Initiatives that expand such support will be important for building a critical support base within local communities.

Sixth, church interventions to date are limited and call for wider cooperation between community, government, law enforcement, and church agencies that can promote meaningful prevention strategies building on human rights, scientific argument and Christian faith.

\section{References}

Damien, C. 2005. The Myth of Kumo: Knowing the Truth about Sanguma in Simbu Province. Catalyst 35(2):114-34.

Eves, R. and A. Kelly-Hanku 2014. Witch-Hunts in Papua New Guinea's Eastern Highlands Province: A Fieldwork Report. SSGM In Brief 2014/4. Canberra: State, Society and Governance in Melanesia Program, The Australian National University.

Gibbs, P. 2004. Growth, Decline and Confusion: Church Affiliation in Papua New Guinea. Catalyst 34(2):164-84. www.philipgibbs.org/pdfs/Growth\% 20 decline.pdf, viewed 19/7/2013.

Gibbs, P. 2009a. Sorcery and AIDs in Simbu, East Sepik and Enga. Occasional Paper 2. Port Moresby: The National Research Institute.

Gibbs, P. 2009b. Forces of Death and the Promise of Life in Papua New Guinea. Australian eJournal of Theology 14. www.acu.edu.au/_data/assets/pdf_ file/0005/197690/Gibbs_-_Death_and_Life_PNG.pdf, viewed 19/7/2013.

Gibbs, P. 2012. Engendered Violence and Witch-Killing in Simbu. In M. Jolly, C. Stewart and C. Brewer (eds.) Engendering Violence in Papua New Guinea. Canberra: ANU E Press, 107-36.

Gibbs, P. and J.J. Wailoni 2009. Sorcery and a Christian Response in the East Sepik. In F. Zocca (ed.) Sanguma in Paradise: Sorcery, Witchcraft and Christianity in Papua New Guinea. Point No. 33. Goroka: Melanesian Institute, 55-96. www.philipgibbs.org/pdfs/SorcerySepik.pdf, viewed 19/7/2013.

Korugl, P. 2006. Catholic Church Warns against Sorcery Violence. The National, 20 October, p. 3.

Schwarz, N. 2011. Thinking Critically about Sorcery and Witchcraft: A Handbook for Christians in Papua New Guinea. Occasional Paper No. 14. Goroka: Melanesian Institute. 
17. Practical Church Interventions on Sorcery and Witchcraft Violence in the Papua New Guinea Highlands

Te Maarssen, H. n.d. Sanguma: A Pastoral Approach. Unpublished paper, Catholic Diocese of Kundiawa, Simbu Province.

Zocca, F. 2005. Witchcraft and Mission in Simbu Province. In P. Gesch (ed.) Mission and Violence: Healing the Lasting Damage. Madang: DWU Press, 109-35.

Zocca, F. (ed.) 2009. Sanguma in Paradise: Sorcery, Witchcraft and Christianity in Papua New Guinea. Point 33. Goroka: Melanesian Institute. 
This text is taken from Talking it Through: Responses to Sorcery and Witchcraft Beliefs and Practices in Melanesia, edited by Miranda Forsyth and Richard Eves, published 2015 by ANU Press, The Australian National University, Canberra, Australia. 